\title{
Multi-Aspect Sentiment Analysis Hotel Review Using RF, SVM, and Naïve Bayes based Hybrid Classifier
}

\author{
I Putu Ananda Miarta Utama, Sri Suryani Prasetyowati, Yuliant Sibaroni* \\ School of Computing, Informatics Study Program, Telkom University, Bandung, Indonesia \\ Email: ${ }^{1}$ anandamiarta@ student.telkomuniversity.ac.id, ${ }^{2}$ srisuryani@ telkomuniversity.ac.id, \\ 3,* yuliant@telkomuniversity.ac.id \\ Correspondence Author Email: yuliant@telkomuniversity.ac.id
}

\begin{abstract}
Abstrak-Dalam sektor pariwisata hotel tentunya tidak lepas dari peran media sosial karena wisatawan cenderung berbagi pengalaman tentang layanan dan produk yang ditawarkan oleh sebuah hotel, seperti menambahkan gambar, review, dan rating yang nantinya akan berguna sebagai referensi bagi wisatawan turis lain, misalnya di media online TripAdvisor. Namun, banyaknya pengalaman wisatawan mengenai hotel membuat sebagian orang bingung menentukan hotel yang tepat untuk dikunjungi. Dengan itu, penelitian ini melakukan analisis review berbasis aspek terhadap hotel, yang akan memudahkan wisatawan dalam menentukan hotel yang tepat berdasarkan aspek kategori terbaik. Dataset yang digunakan adalah dataset Ulasan Hotel TripAdvisor yang sudah ada di situs web Kaggle. Serta memiliki lima aspek yaitu Kamar, Lokasi, Kebersihan, Pendaftaran, dan Pelayanan. Analisis review dilakukan ke dalam kategori positif dan negatif dengan Random Forest, SVM, dan Naive Bayes berbasis Hybrid Classifier untuk mengatasi masalah ini. Pada penelitian ini metode Hybrid Classifier mendapatkan akurasi yang lebih baik dibandingkan dengan klasifikasi yang menggunakan satu algoritma pada data multi aspek yaitu Hybrid Classifier mendapatkan rata rata akurasi $84 \%$, Naïve Bayes mendapatkan rata rata akurasi 82.4\%, Random Forest mendapatkan rata rata akurasi $82.2 \%$, dan SVM mendapatkan rata rata akurasi $81 \%$.
\end{abstract}

Kata Kunci: Hotel, Random Forest, SVM, Hybrid Classifier, Multi-aspek Analisis Sentiment, Nä̈ve Bayes

\begin{abstract}
In the hotel tourism sector, of course, it cannot be separated from the role of social media because tourists tend to share experiences about services and products offered by a hotel, such as adding pictures, reviews, and ratings which will be helpful as references for other tourists, for example on the media online TripAdvisor. However, tourists' many experiences regarding a hotel make some people feel confused in determining the right hotel to visit. Therefore, in this study, an aspectbased analysis of reviews on hotels is carried out, which will make it easier for tourists to determine the right hotel based on the best category aspects. The dataset used is the TripAdvisor Hotel Reviews dataset which is already on the Kaggle website. And has five aspects, namely Room, Location, Cleanliness, Registration, and Service. A review analysis was carried out into positive and negative categories using the Random Forest, SVM, and Naive Bayes based Hybrid Classifier methods to solve this problem. In this study the Hybrid Classifier method gets better accuracy than the classification using one algorithm on multi-aspect data, namely the Hybrid Classifier got an average accuracy $84 \%$, Naïve Bayes got an average accuracy $82.4 \%$, Random Forest got an average accuracy $82.2 \%$, and use SVM got an average accuracy $81 \%$.
\end{abstract}

Keywords: Hotel; Random Forest; SVM; Hybrid Classifier; Multi-aspect Sentiment Analysis; Naïve Bayes

\section{INTRODUCTION}

In the current development of tourism, it cannot be separated from online media because it is beneficial for tourists in finding and referencing the tourism they want, one of which is tourism in hotel destinations. Hotels are essential in the world of tourism because every tourist uses hotels to rest after traveling. Travelers tend to share experiences or express themselves about a hotel's services and products on online media such as TripAdvisor. TripAdvisor is one of the online media or travel websites that can help tourists book hotels quickly. Tourists can also access and add images, reviews, and ratings of a hotel they have visited, which will later be helpful as a reference for other tourists.

Based on research [1], prove that $89 \%$ travelers and $64 \%$ hotel owner believe that a reviews of hotel affect the booking decision of hotel, based on the data that nearly $95 \%$ of travelers make a booking decision by first reading hotel reviews online, and this is one of the most important influences of a traveler's decision to choose a hotel. Online ratings and customer reviews can help customers make decisions, but studies provide a better insight into the hotel [2]. There are many reviews about too available hotels or do not contain certain aspects on the online media or the TripAdvisor website. It makes it difficult for other travelers to decide to book the best hotel.

Previous research [3] resulted in an average F1 score of $91.4 \%$ on hotel review sentiment analysis, but an aspect-based analysis of hotel reviews has not been carried out. By using multi-aspect sentiment analysis, users can more easily determine something according to the aspect category that the user sees. There are five aspects of the hotel category in multi-aspect sentiment analysis research: location, food, service, comfort, and cleanliness, which get the highest accuracy results reaching 93\% in these five aspects [1]. In contrast to the research [4], five elements of the category used: service, room, location, price, and food, which results in Precision, Recall, and F1 Score almost reaches above $70 \%$ in all aspects except the food aspect. In the study [5], the F1- Measure result was 0.840 in 5 hotel categories: location, food, service, comfort, and cleanliness. Sentiment classification yields F1Size 0.946.

Referring to previous research that used 1000 data from the Amazon site with Random Forest technique and SVM dependent on the Hybrid in sentiment analysis, the accuracy of $81 \%$ Random Forest classification, 
82.4\% SVM and Hybrid was gotten 83.4\% [6]. Using Hybrid can increase the efficiency of sentiment analysis and get more accurate results than other algorithms. The study [7], which used the SVM algorithm and Hybrid-based Artificial Neural Networks, obtained high accuracy results, namely $97.4 \%$ in film review data. Research using the Hybrid method also obtained $93 \%$ accuracy results using the movie review dataset, which combines two different machine learning algorithms, namely Naïve Bayes and Artificial Genetic Algorithm [8]. However, these three studies have not used multi-aspect sentiment analysis. It is an opportunity for further research. Naïve Bayes Classifier will add in the method study.

Based on these problems, this study conducted a Multi-Aspect Analysis of Hotel Review Sentiments Using Random Forest, SVM, and Naïve Bayes based on Hybrid Classifier. Sentiment analysis will reveal both positive and negative reviews so that users can quickly determine the best judgments. The data set used 1,500 datasets for Hotel Reviews from TripAdvisor in English, which are already on the Kaggle website. This study will be Five aspects: rooms, location, cleanliness, check-in, and service. Sentiment labeling on multi-aspect data is done manually, where the sentiment will be labeled positive and negative based on each aspect of the hotel review.

This study aims to conduct multi-aspect sentiment analysis to assist the tourists choose the good hotel based on the ideal class aspect. Then, conducted this research to determine the results of the classification and performance of the method use Random Forest, SVM, and Naïve Bayes method based on Hybrid Classifier on several aspects of sentiment analysis based on hotel reviews.

The next section of this research is part 2, which will discuss the research methodology that will be used in this research, in section 3 discusses the discussion of the process carried out and the results obtained after conducting this research, and section 4 discusses the conclusions and suggestions after doing this research.

\section{RESEARCH METHODOLOGY}

\subsection{Literature Review}

In research [2], the Sentiment-Oriented Summarization-based aspects of Hotel Review revealed that assessing hotels based on aspects provides a better understanding than others according to user comments, and this can further help customers in the decision-making process which hotel to choose according to their needs and help management hotel because they will now realize which areas they need to improve and what their strengths are. A multi-aspect sentiment analysis regarding hotel reviews has been carried out in previous studies, where there are five category aspects in hotel reviews [1]. In this study, a multi-aspect sentiment analysis experiment was carried out using Latent Dirichlet Allocation (LDA) to determine hidden topics from the glossary, Semantic Similarity to categorize data, and a mix of Word Embedding and Long-short Term Memory (LSTM) for classification. In multiaspect research using LDA + TF-ICF 100\% + Semantic Similarity resulted in the highest F1- Measure 85\% and Word Embedding + LSTM resulted in the F1- Measure 93\% classification.

Research [4] conducted a sentiment analysis based on the hotel's aspects using the SVM and Naive Bayes, which used the TF-IDF. Aspects reviewed in this study are location, room, food, price, and service, which are manually labeled positive and negative. In this research, using a SVM results in better and more effective accuracy than Naive Bayes in all these aspects. The results are more than $70 \%$ accurate in all aspects except the food aspect. Multi aspects of sentiment analysis about hotels have also been carried out in this study [5]. Using PLSA + TF ICF $100 \%$ + Semantic Similarity, this research resulted in F1-Measure 84\% on the five aspects of the hotel being reviewed, namely Location, Meal, Service, Comfort, and Cleanliness.

A hybrid technique dependent on Random Forest and SVM has been used in this research [6]. This study using product review data from Amazon, where the Random Forest approach improves performance in a small review and the SVM improves performance when an extensive review works as a single hybrid approach. Accuracy of Random Forest classification is $81 \%$, SVM 82.4\%, and Hybrid 83.4\% [6]. Hybrid use was also used in a movie review in this study [8]. Hybrid Naive Bayes - Genetic Algorithm gets an excellent accuracy of $93 \%$. The comparison between individual classifiers and hybrid classifiers in this study shows that the hybrid classifiers significantly improve the single classifier. In the study [9], the hybrid classifier improved accuracy and achieved a significant breakthrough in reducing GPU processing power. Researched the Rule-Based, Lexicon Based, Machine Learning and Hybrid classifier in this study, and the Hybrid Approach obtained the highest F-score, namely $61.81 \%$.

The method author use is a Hybrid method on three classifications, namely Random Forest, SVM, and Naïve Bayes, which will be used in multi-aspect sentiment analysis. A study conducted by Savita Sangam and Subhash Shinde using the Hybrid SVM and ANN in the movie review successfully improved classification performance in sentiment analysis [7]. And in research [4], multi-aspect sentiment analysis helps determine hotel services' customer reviews.

\subsection{Random Forest}


Random Forest is essential for a mechanized learning strategy. Random Forest has different choice trees, and every choice tree will be an all out development. No compelling reason to cut preparing. The more trees it has, improve accurate the results, not too much [10]. Random Forest is important for a family assortment technique that takes a choice tree. They depend on the Bagging, Randomizing result, and Subspace techniques, which is the justification the improvement [6]. Figure 4 is an example of a Random Forest portrayal utilizing bootstrap to remove k examples from the first preparing set with $\mathrm{N}$ tests for $\mathrm{k}$ occasions, set $\mathrm{k}$ choice trees, and select as per all choice tree order results. We can describe the voting effect called confidence score in (1):

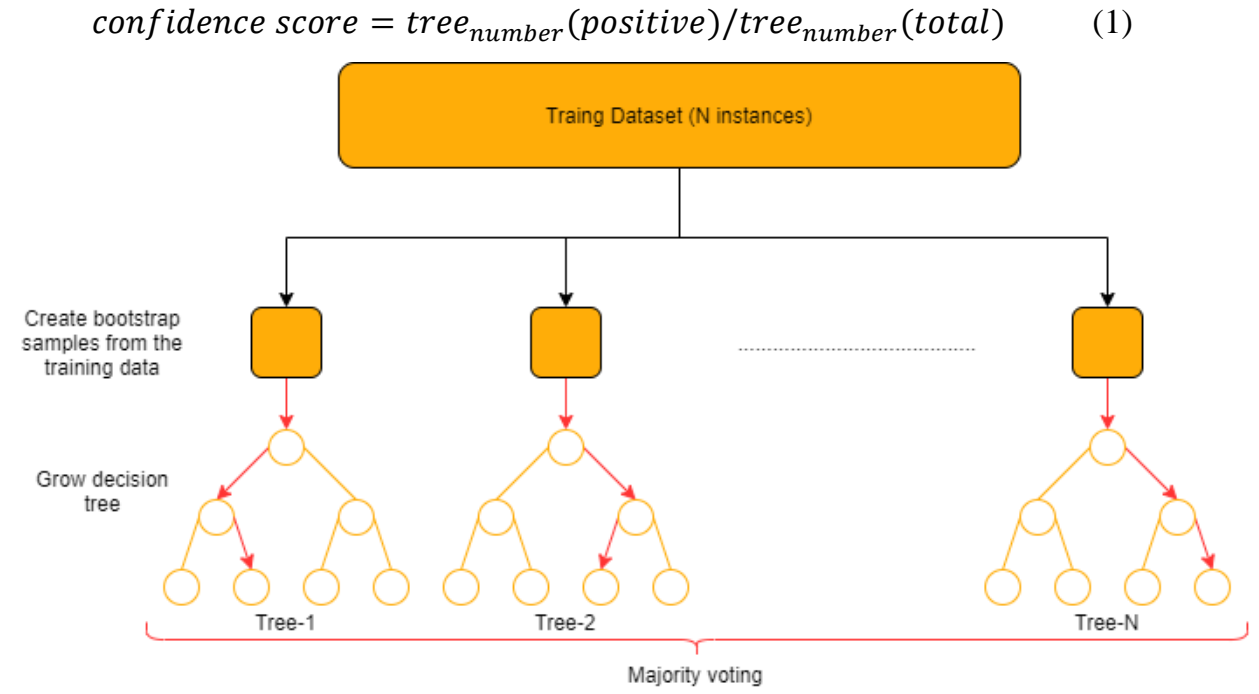

Figure 1. Representation of Random Forest

Random Forest algorithm truly outstanding among characterization calculations [6] in light of the fact that it can group a lot of information precisely. Random forest uses a collection of decision trees to gather information. The calculation formula is presented in (2) and (3) [11]:

$$
\begin{aligned}
& \inf _{O_{A}}(D)=-\sum_{i=1}^{m} p_{i} \log _{2} p_{i} \\
& \operatorname{gain}(A)=\inf _{O}(D)-\inf _{O_{A}}(D)
\end{aligned}
$$

The output class is selected based on a majority vote i.e., the maximum number of similar courses produced by various trees is considered to be output from Random Forest [12].

\subsection{Support Vector Machine (SVM)}

The SVM technique measurable grouping method dependent on boosting the edge among occasions and hyperplane partition [6]. SVM isn't probabilistic twofold straight classifier that can isolate classes directly with a huge wiggle room. It is perhaps the most impressive classifiers equipped for taking care of boundless dimensional component vectors. To maximization the margin in the SVM, use formula (5):

$$
\min _{w} \frac{1}{2}(\|w\|)^{2}
$$

The limitation to maximalization the margin use formula (5):

$$
y_{i}\left(x_{i} * w+b\right)-1 \geq 0
$$

After that, calculate the elimination to get $\mathrm{w}$ and $\mathrm{b}$ use formula (6), (7), and (8):

$$
\begin{array}{ll}
x_{i} * w+b=0 & \\
x_{i} * w+b \geq+1 & \text { Untuk } y_{i}=+1 \\
x_{i} * w+b \leq-1 & \text { Untuk } y_{i}=-1
\end{array}
$$

$x_{i}$ is the measurement vector, $\mathrm{w}$ means weight vector, $\mathrm{b}$ is the predisposition worth, and $\mathrm{y}$ is the class. From equation (6) is the hyperplane to separation class positive and negative. Equation (7) is used in the study positive value and equation (7) to the negative class value. We will use the research a linear kernel because it is suitable and straightforward to use in data with many features.

\subsection{Naïve Bayes}


Naïve Bayes is a characterization calculation utilizing likelihood and measurable techniques by the British researcher Thomas Bayes [4]. This examination will utilize Multinomial Nave Bayes in light of the fact that the Multinomial Nave Bayes Classifier is an administered learning technique that utilizes likelihood and is centered around the situation of text arrangement [3]. Our information highlights in vector portrayal or discrete structure. Additionally, this technique unequivocally expects autonomy between the actual highlights. In a report, the likelihood appropriation of words from w_1 to w_n, for a given class c, can be determined by the Bayes recipe [13], as displayed in condition 6:

$$
P(c \mid d) \propto P(c) \prod_{i=1}^{n_{d}} P\left(w_{i} \mid c\right)
$$

$P\left(w_{i} \mid c\right)$ is the likelihood that a few words show up in class c. $P(c)$ is the past likelihood in class c. $P(c \mid d)$ is the likelihood class $\mathrm{c}$ in archive d. Class assurance is by contrasting the aftereffects of the back likelihood got, then, at that point the class with the best back likelihood is the class picked as the expectation result [3]. The past likelihood recipe:

$$
P(c)=\frac{N_{c}}{N}
$$

$N_{c}$ is the amount of angle $c$, and $N$ is the amount, all things considered. The probability likelihood recipe:

$$
P\left(t_{k} \mid c\right)=\frac{T_{t c}}{\sum t^{\prime} \in V^{T} c t^{\prime}}
$$

$T_{t c}$ or total probability words in category c, and $\sum t^{\prime} \in V^{T} c t^{\prime \prime}$ is the all out likelihood of all words in class c.

\subsection{Hybrid Classifier}

The Hybrid Classifier method combines at least two techniques to improve the new technique's performance. The aim is to get the advantages of several combined techniques so that the Hybrid Classifier created has better accuracy. The Hybrid Classifier technique utilizes outfit gaining from the Random Forest Classifier, SVM, and Naïve Bayes method. The ensemble method is a meta-algorithm that combines many algorithms in classification to get a new model with better performance. Stacking is one of the ensemble models, which make a new model from combined predictions of 2 or more classifications.

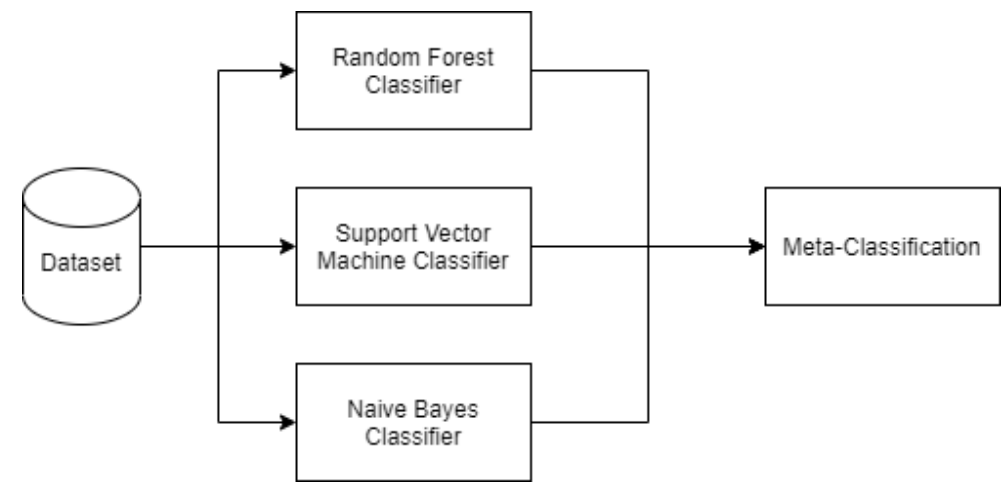

Figure 2. Design of Stacking Ensemble Method

\subsection{Evaluation}

Evaluate system performance to measure system performance. Measurement of system performance in this study will use accuracy, precision, and recall originating from the confusion matrix. The following is a formula for accuracy, precision, and recall:

$$
\begin{aligned}
& \text { Accuracy }=\frac{T P+T N}{T P+T N+F P+F N} \times 100 \% \\
& \text { Precision }=\frac{T P}{T P+F P} \times 100 \% \\
& \text { Recall }=\frac{T P}{T P+F N} \times 100 \%
\end{aligned}
$$

For every blend, the presence of the component is positive as P and negative as N. The documentation TP (True Positives) is the quantity in the tests that are anticipated to be positive will be positive, and FP (False Positives) is the quantity in the models relied upon to be positive which is negative, TN is True Negatives: the quantity of tests that are anticipated to be alternate extremes is negative, FN is False Negatives: the quantity of tests predicts cynicism positive ones. In light of the TP, FP, FN, and TN esteems, the exactness, accuracy, and review esteems will be gotten. The precision esteem depicts how precisely the framework can group the information effectively. 
The exactness esteem addresses the precision between the information and the expectation given by the framework. While review is the degree of achievement of the framework in recuperating data information. The exactness esteem portrays the precision between the information and the expectations given by the framework. While review is the achievement pace of the framework in recuperating data information.

\section{RESULTS AND DISCUSSION}

\subsection{Design Scheme}

In general, the steps for creating a system that performs sentiment analysis using Machine Learning are Dataset, Data Preprocessing, Feature Extraction, Modeling, and Evaluation. The course will produce a classification model that is utilized to characterize the slant examination. The following is the design scheme to be built:

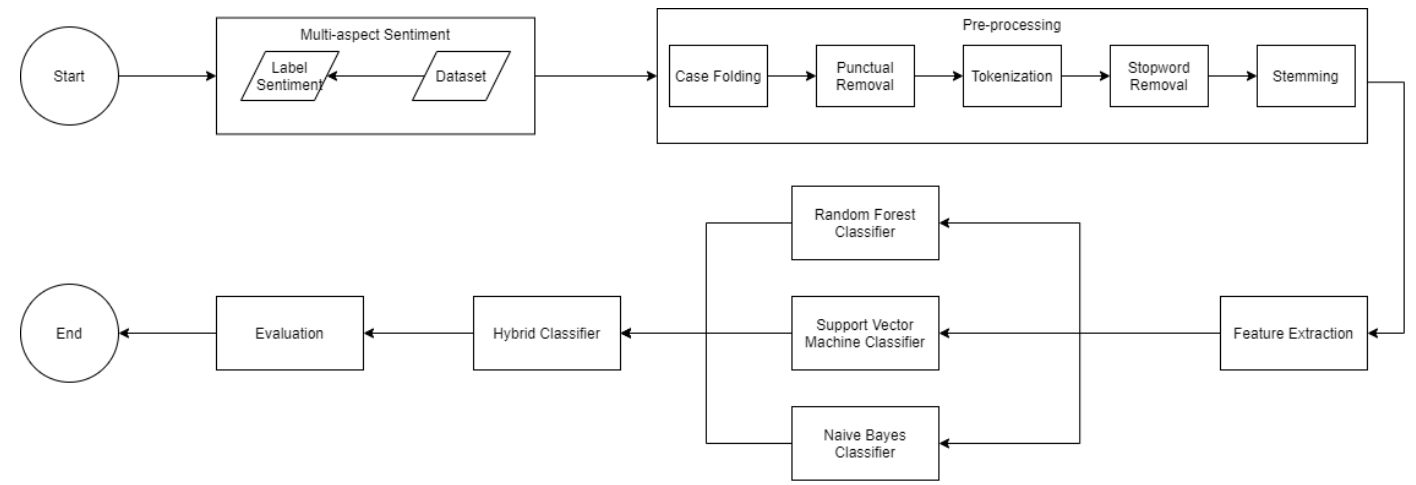

Figure 3. Design Scheme

\subsection{Multi-aspect Sentiment}

Sentiment Analysis means a computational report to identify, express opinions, sentiments, evaluations, attitudes, emotions, subjectivity, judgments, or views contained in a text [14]. Multi Aspects Sentiment Analysis is a detailed sentiment analysis technique using the category aspect of an opinion on each data. Using multi-aspect sentiment analysis, users can more easily determine something according to the category aspect that the user is desired. The main benefit of the multi-task framework is that it can mutually enhance aspect rating prediction between different aspects [15].

\subsubsection{Dataset}

The dataset utilized is dataset taken from the Kaggle website. This dataset is a dataset about Hotel Reviews based on reviews from hotel visitors from the TripAdvisor application. The amount of data from the dataset is 1500 reviews about hotels in English. Table 1 is an example of a hotel review data set that will be used.

Table 1. Dataset

\begin{tabular}{l} 
Review \\
\hline Very comfortable This is a very comfortable hotel located next to Universal. Walk or \\
take the shuttle. The room on the 12th floor ( we got an upgrade) was very nice with a \\
great view. Would stay here again. \\
The hotel is a dirty and bad smell in the hotel. I will not recommend you to stay in this \\
hotel!!! \\
Great service, location amazing, able to walk Safeco field distance shopping public \\
market, decided on the simple monorail walk a couple of squares away. the rooms are \\
decent perfect and agreeable. check-in also easy and professional
\end{tabular}

\subsubsection{Label Sentiment}

There will be 5 (five) kinds of aspects being reviewed in this research, namely Room, Location, Cleanliness, Check-in, and Service. Five aspects are based on hotel visitor reviews made on the TripAdvisor Hotel Review dataset from the Kaggle Website. Sentiment labeling is done manually on hotel review data based on the aspects being reviewed. And in Table 2 are examples of data set labeling done where 1 represents Positive, and -1 represents Negative:

Table 2. Labeling Dataset 


\begin{tabular}{|c|c|c|c|c|c|}
\hline Review & Room & Location & Cleanliness & Check-in & Service \\
\hline $\begin{array}{l}\text { Very comfortable This is a very comfortable hotel } \\
\text { located next to Universal. Walk or take the shuttle. } \\
\text { The room on the } 12 \text { th floor ( we got an upgrade) was } \\
\text { very nice with a great view. Would stay here again. }\end{array}$ & 1 & 1 & & & \\
\hline $\begin{array}{l}\text { The hotel is a dirty and bad smell in the hotel. I will } \\
\text { not recommend you to stay in this hotel!!! }\end{array}$ & & & -1 & & \\
\hline $\begin{array}{l}\text { Great service, location amazing, able to walk Safeco } \\
\text { field distance shopping public market, decided on the } \\
\text { simple monorail walk a couple of squares away. the } \\
\text { rooms are decent perfect and agreeable. check-in } \\
\text { also easy and professional }\end{array}$ & 1 & 1 & 1 & 1 & 1 \\
\hline
\end{tabular}

\subsection{Data Pre-processing}

Pre-processing is done to get the best results by reducing noise in hotel review data. Pre-processing is a step taken to prepare data before analyzed in the sentiment classification process [4]. Pre-processing will handle imperfect data. This study's pre-processing process is case folding, punctual removal, tokenization, stop-word, and stemming.

Table 3. Description and Example of Pre-processing

\begin{tabular}{|c|c|}
\hline Pre-processing & Description \\
\hline Case Folding & $\begin{array}{l}\text { Case Folding is change letters to the lowercase. Examples on sentences " The hotel is a } \\
\text { dirty and bad smell in the hotel. I will not recommend you to stay in this hotel!!!" } \\
\text { becomes "the hotel is a dirty and bad smell in the hotel. i will not recommend you to stay } \\
\text { in this hotel!!!" }\end{array}$ \\
\hline Punctual Removal & $\begin{array}{l}\text { Punctual removal is a process to get rid of punctuation marks. An Example of the } \\
\text { sentence " the hotel is a dirty and bad smell in the hotel. i will not recommend you to } \\
\text { stay in this hotel!!!" becomes "the hotel is a dirty and bad smell in the hotel i will not } \\
\text { recommend you to stay in this hotel" }\end{array}$ \\
\hline Tokenization & $\begin{array}{l}\text { Tokenization is the process of separating a sentence into one part or word. Example of } \\
\text { the sentence " the hotel is a dirty and bad smell in the hotel i will not recommend you to } \\
\text { stay in this hotel " becomes '['the', 'hotel', 'is', 'a', 'dirty', 'and', 'bad', 'smell', 'in', } \\
\text { 'the', 'hotel', 'i', 'will', 'not', 'recommend', 'you', 'to', 'stay', 'in', 'this', 'hotel']. " }\end{array}$ \\
\hline Stop-word & $\begin{array}{l}\text { Stop-word is the process of eliminating meaningless words. Example of the sentence } \\
\text { "['the', 'hotel', 'is', 'a', 'dirty', 'and', 'bad', 'smell', 'in', 'the', 'hotel', 'i', 'will', 'not', } \\
\text { 'recommend', 'you', 'to', 'stay', 'in', 'this', 'hotel']. " becomes '['hotel', 'dirty', 'bad', } \\
\text { 'smell', 'hotel', 'recommend', 'stay', 'hotel']." }\end{array}$ \\
\hline Stemming & $\begin{array}{l}\text { Stemming is removing affixes to words or basic word. Example of the sentence "['hotel', } \\
\text { 'dirty', 'bad', 'smell', 'hotel', 'recommend', 'stay', 'hotel']." becomes "[' 'hotel', 'dirty', } \\
\text { 'bad', 'smell', 'hotel', 'recommend', 'stay', 'hotel']." }\end{array}$ \\
\hline
\end{tabular}

\subsection{Feature Extraction}

At this stage, the researcher uses the Bag of Words. Bag of Words is a simplified representation of natural language processing, where the text will be represented as a number in the document classification which then becomes a vector [16]. Use of classifications with Bag of Words to practice categorizing features.

Table 4. Representation of Bag of Words

\begin{tabular}{cccccccc}
\hline Review & hotel & dirty & bad & smell & recommend & stay & Vector \\
\hline R1 & 1 & 0 & 0 & 0 & 0 & 1 & {$[1,0,0,0,0,1]$} \\
R2 & 3 & 1 & 1 & 1 & 1 & 1 & {$[3,1,1,1,1,1]$} \\
R3 & 0 & 0 & 0 & 0 & 0 & 0 & {$[0,0,0,0,0,0]$} \\
\hline
\end{tabular}

\subsection{Model Classification}

From the model we test to use the dataset has a positive review for Hotel Room with 578 and negative review for Room Hotel with 191, a positive review for Hotel Location with 633 and negative review for Hotel Location with 
156, a positive review for Hotel Cleanliness with 371 and negative review for Hotel Cleanliness 155, positive reviews for Hotel Check-In 332, and negative reviews for Hotel Check-In 116, positive reviews for Hotel Service 711 , and negative reviews about Hotel Service 185. The dataset we split $30 \%$ to use data test and $70 \%$ to data train with random state 0 .

\subsubsection{Random Forest}

This algorithm to train using the Random Forest method:

Table 5. Algorithm Random Forest

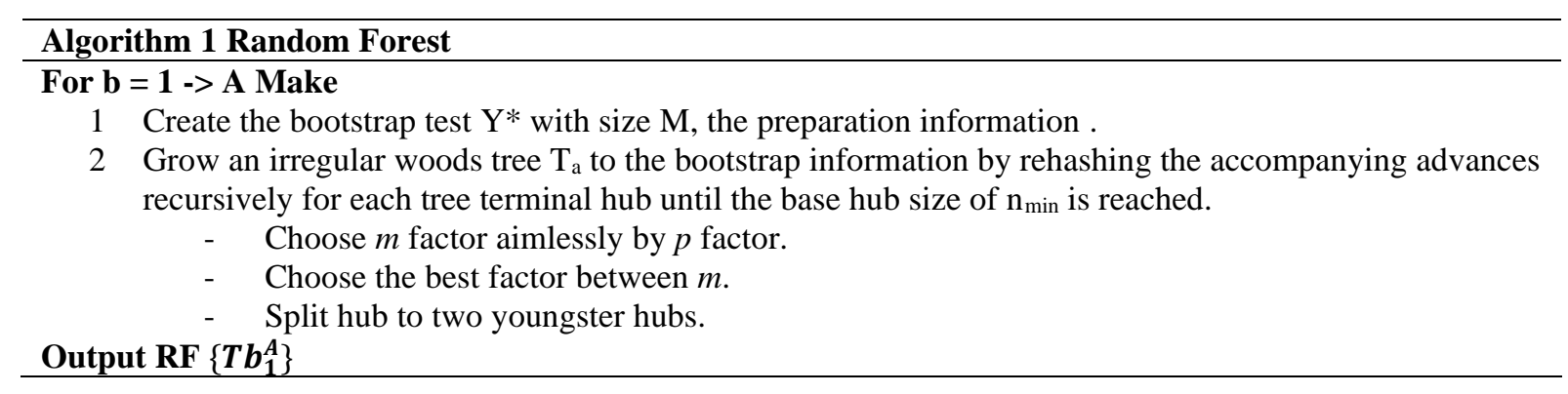

\subsubsection{SVM}

This algorithm to train using the SVM method:

Table 6. Algorithm SVM

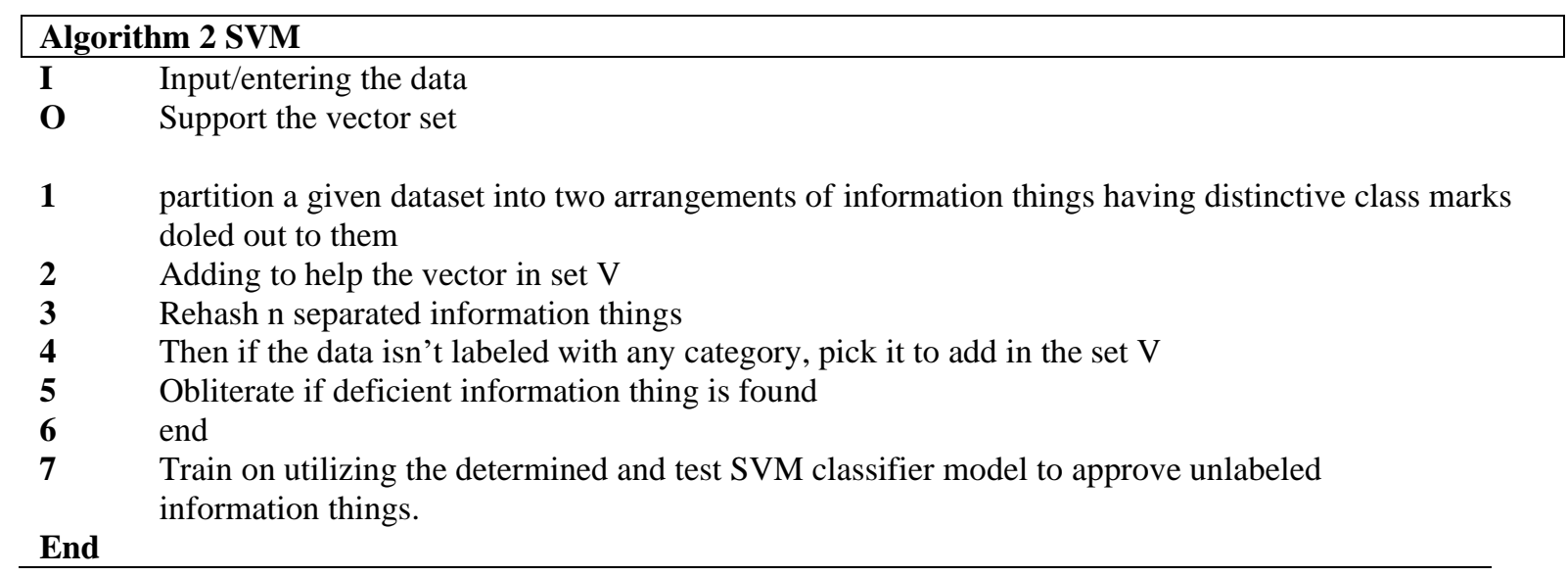

\subsubsection{Naïve Bayes}

The following this algorithm to train using the Multinomial Naïve Bayes method:

Table 7. Algorithm Multinomial Naïve Bayes

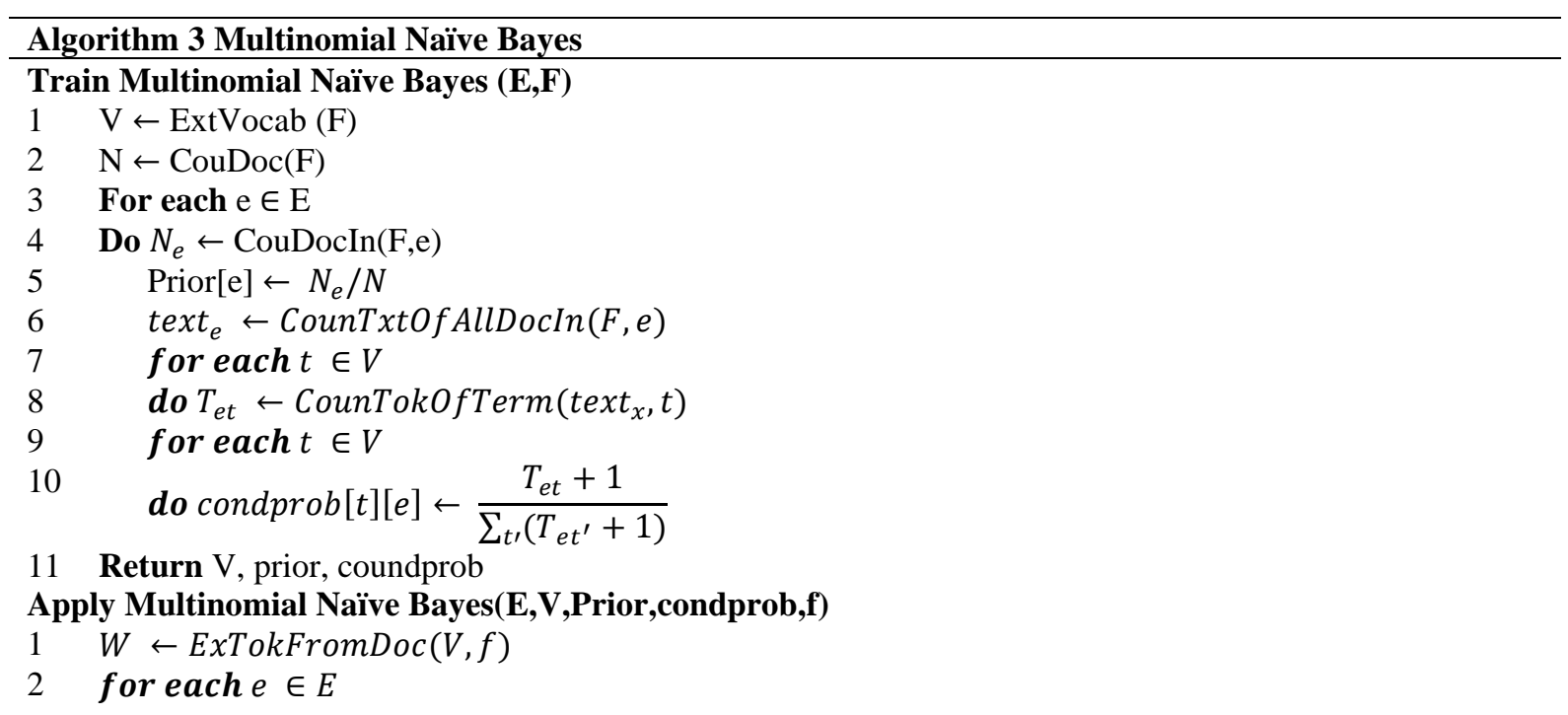


ISSN 2614-5278 (media cetak), ISSN 2548-8368 (media online)

Available Online at https://ejurnal.stmik-budidarma.ac.id/index.php/mib

DOI 10.30865/mib.v5i2.2959

3 do score $[e] \leftarrow \log$ prior $[e]$

4 for each $t \in W$

5 do score $[e]+=\log$ conprob $[t][e]$

6 Return arg $\max _{e \in C} \operatorname{score}[e]$

\subsubsection{Hybrid Classifier}

The following this algorithm to train using the Hybrid Classifier method:

Table 8. Algorithm Hybrid RF-SVM-NB

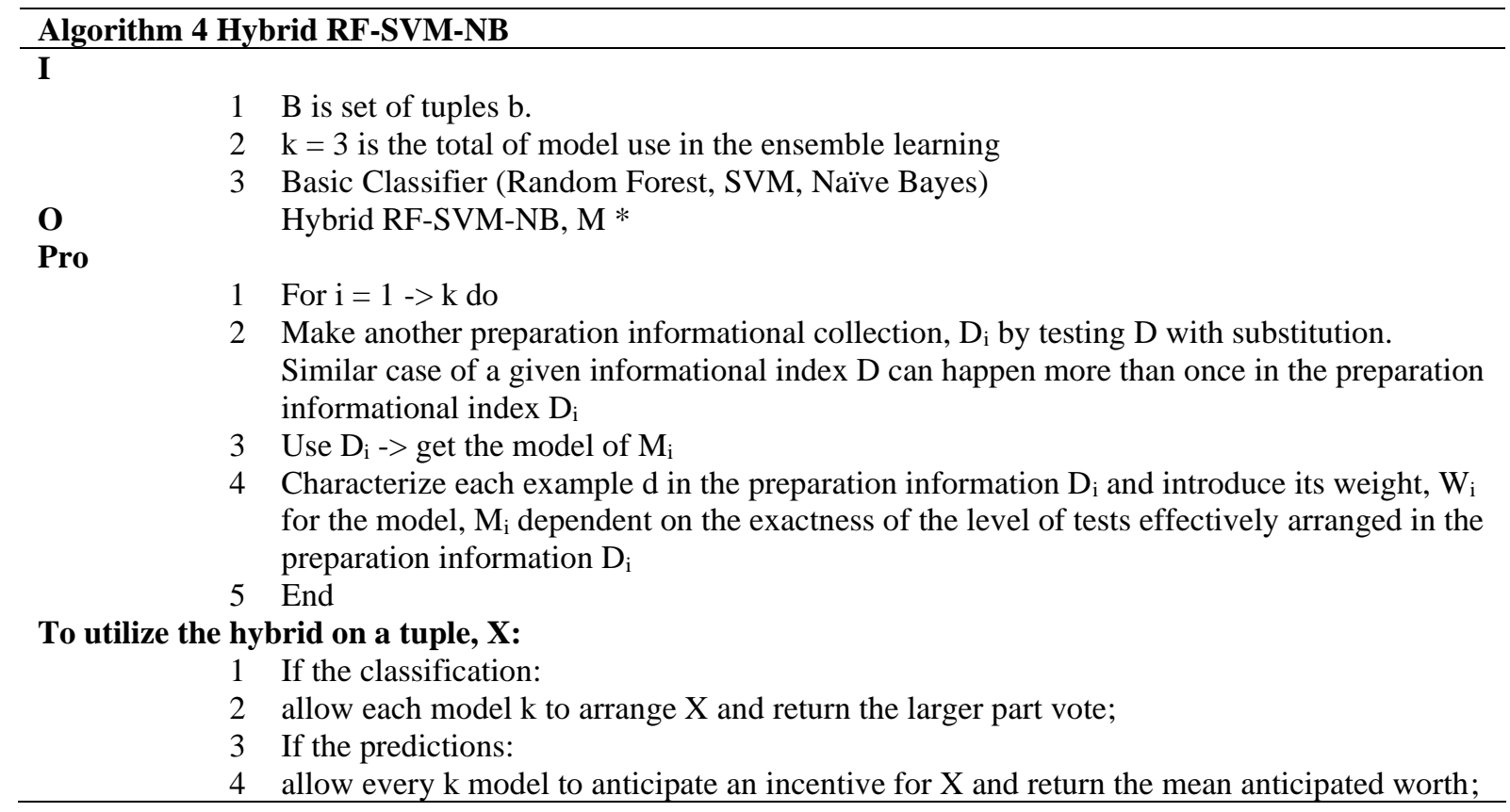

\subsubsection{Evaluation}

The final result in this research, shown in Table 9 about the Precision, Recall, F1-Score, and Accuracy in every classification aspect from data. The result almost reached $80 \%$ in all aspects except Check-In using SVM Classification.

Table 9. Evaluation of Classifier

\begin{tabular}{|c|c|c|c|c|c|c|c|}
\hline Aspect & Positive & Negative & Classification & Precision & Recall & F1-Score & Accuracy \\
\hline \multirow{4}{*}{ Room } & \multirow{4}{*}{578} & \multirow{4}{*}{191} & SVM & 0.75 & 0.78 & 0.76 & 0.83 \\
\hline & & & $\mathrm{RF}$ & 0.81 & 0.72 & 0.75 & 0.85 \\
\hline & & & NB & 0.77 & 0.79 & 0.78 & 0,84 \\
\hline & & & Hybrid & 0.76 & 0.77 & 0.77 & 0.84 \\
\hline \multirow{4}{*}{ Location } & \multirow{4}{*}{578} & \multirow{4}{*}{191} & SVM & 0.73 & 0.73 & 0.73 & 0.81 \\
\hline & & & $\mathrm{RF}$ & 0.79 & 0.72 & 0.74 & 0.80 \\
\hline & & & NB & 0.70 & 0.69 & 0.69 & 0.80 \\
\hline & & & Hybrid & 0.77 & 0.70 & 0.72 & 0.84 \\
\hline \multirow{4}{*}{ Cleanliness } & \multirow{4}{*}{578} & \multirow{4}{*}{191} & SVM & 0.81 & 0.81 & 0.81 & 0.84 \\
\hline & & & RF & 0.79 & 0.72 & 0.74 & 0.80 \\
\hline & & & NB & 0.83 & 0.80 & 0.81 & 0.85 \\
\hline & & & Hybrid & 0.84 & 0.79 & 0.81 & 0.85 \\
\hline \multirow{4}{*}{ Check-in } & \multirow{4}{*}{578} & \multirow{4}{*}{191} & SVM & 0.65 & 0.66 & 0.66 & 0.76 \\
\hline & & & $\mathrm{RF}$ & 0.74 & 0.59 & 0.60 & 0.80 \\
\hline & & & NB & 0.72 & 0.74 & 0.73 & 0.80 \\
\hline & & & Hybrid & 0.74 & 0.74 & 0.74 & 0.82 \\
\hline \multirow{4}{*}{ Service } & \multirow{4}{*}{578} & \multirow{4}{*}{191} & SVM & 0.72 & 0.71 & 0.71 & 0.81 \\
\hline & & & $\mathrm{RF}$ & 0.84 & 0.60 & 0.61 & 0.82 \\
\hline & & & NB & 0.76 & 0.74 & 0.75 & 0.83 \\
\hline & & & Hybrid & 0.79 & 0.75 & 0.77 & 0.85 \\
\hline
\end{tabular}


ISSN 2614-5278 (media cetak), ISSN 2548-8368 (media online)

Available Online at https://ejurnal.stmik-budidarma.ac.id/index.php/mib DOI 10.30865/mib.v5i2.2959

From all table in every method is the result of classification we can average with equation (12):

$$
\text { Average }=\frac{\text { Total sum of all accuracy aspects }}{\text { Number of aspects }}
$$

The final result is represented in the table about the accuracy. Using Random Forest in multi-aspect data gets average accuracy of $81 \%$. Using SVM in multi-aspect data gets average accuracy of $82.2 \%$. Naïve Bayes in multiaspect data gets average accuracy of $82.4 \%$ and uses Hybrid Classifier in multi-aspect data get average accuracy of $84 \%$. Using Random Forest in aspect data Rooms is better than Hybrid. Still, Hybrid classification utilizing Random Forests Classification, SVM, and Naïve Bayes improve result than utilizing a single classification method if we average all accuracy result in every aspect of data. Hybrid can work on the exactness and execution of order. Figure 4, it is obvious that Random Forest Classification, SVM and Naive Bayes based on Hybrid shows the better result contrasted with other contemplated calculations.

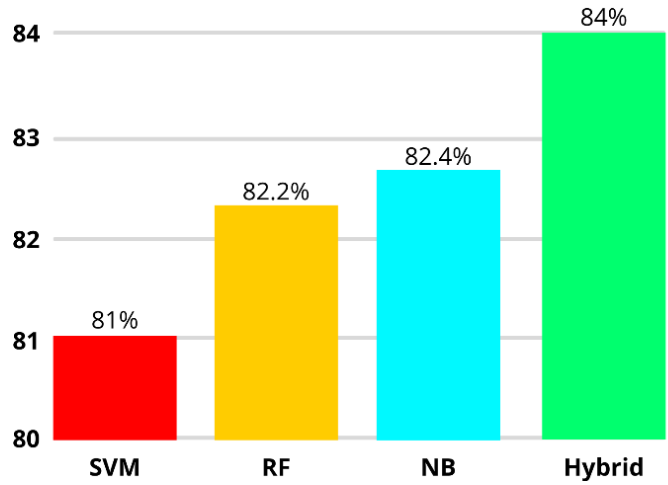

Figure 4. Average Classification Method Result

\section{CONCLUSION}

Multi-Aspect Sentiment Analysis is a technique of analyzing a person's opinion or judgment, specifically using certain aspects of each data category. In this study, there are five aspects of the hotel category in the data being reviewed: room, location, cleanliness, check-in, and service. The dataset has positive reviews for Hotel Room with 578 and negative reviews for Hotel Room with 191, positive review for Hotel Location with 633 and negative review for Hotel Location with 156, positive review for Hotel Cleanliness with 371 and negative review for Hotel Cleanliness 155, reviews positive reviews for Hotel Check-In 332, and negative reviews for Hotel Check-In 116, positive reviews for 711 Hotel Services, and negative reviews about Hotel Services 185. The technique used are Random Forest Classification, SVM and Naïve Bayes based on Hybrid. The Random Forest method results produce an average accuracy $82.2 \%$, so it's better than Classification SVM is average accuracy $81 \%$. The best result from the three classification methods is Naïve Bayes, with an average accuracy $82.4 \%$. Hybrid can improves results than utilizing a single classification method with an average accuracy $84 \%$. It can prove that hybrids can further develop the final accuracy and performance in multi-aspect sentiment analysis data. This research also proves again from previous research that the hybrid classifier can improve accuracy and apply to the case study conducted in this study, namely using multi-aspect sentiment data. We can make a few ideas in additional exploration; in particular, the information can utilize Indonesian and use include weighting with TF-IDF. Further research can also add new classification methods to be used in hybrid ways.

\section{REFERENCES}

[1] R. A. Priyantina and R. Sarno, "Sentiment analysis of hotel reviews using Latent Dirichlet Allocation, semantic similarity and LSTM," Int. J. Intell. Eng. Syst., vol. 12, no. 4, pp. 142-155, 2019, doi: 10.22266/ijies2019.0831.14.

[2] N. Akhtar, N. Zubair, A. Kumar, and T. Ahmad, "Aspect based Sentiment Oriented Summarization of Hotel Reviews," Procedia Comput. Sci., vol. 115, no. May 2020, pp. 563-571, 2017, doi: 10.1016/j.procs.2017.09.115.

[3] A. A. Farisi, Y. Sibaroni, and S. Al Faraby, "Sentiment analysis on hotel reviews using Multinomial Naïve Bayes classifier," J. Phys. Conf. Ser., vol. 1192, no. 1, 2019, doi: 10.1088/1742-6596/1192/1/012024.

[4] F. A. Bachtiar, W. Paulina, and A. N. Rusydi, "Text Mining for Aspect Based Sentiment Analysis on Customer Review : a Case Study in the Hotel Industry," 5th Int. Work. Innov. Inf. Commun. Sci. Technol., no. March, 2020.

[5] D. A. K. Khotimah and R. Sarno, "Sentiment analysis of hotel aspect using probabilistic latent semantic analysis, word embedding and LSTM," Int. J. Intell. Eng. Syst., vol. 12, no. 4, pp. 275-290, 2019, doi: 10.22266/ijies2019.0831.26.

[6] Y. Al Amrani, M. Lazaar, and K. E. El Kadirp, "Random forest and SVM based hybrid approach to sentiment analysis," Procedia Comput. Sci., vol. 127, pp. 511-520, 2018, doi: 10.1016/j.procs.2018.01.150.

[7] S. Sangam and S. Shinde, "Sentiment classification of social media reviews using an ensemble classifier," Indones. J. Electr. Eng. Comput. Sci., vol. 16, no. 1, p. 355, 2019, doi: 10.11591/ijeecs.v16.i1.pp355-363.

[8] M. Govindarajan, "Sentiment Analysis of Movie Reviews using Hybrid Method of Naive Bayes and Genetic Algorithm," Int. J. Adv. Comput. Res., no. 4, pp. 2277-7970, 2013, [Online]. Available: http://imdb.com.

[9] A. Sharma, A. Sharma, R. K. Singh, and M. D. Upadhayay, "Hybrid Classifier for Sentiment Analysis Using Effective Pipelining," Int. 
JURNAL MEDIA INFORMATIKA BUDIDARMA

Volume 5, Nomor 2, April 2021, Page 630-639

ISSN 2614-5278 (media cetak), ISSN 2548-8368 (media online)

Available Online at https://ejurnal.stmik-budidarma.ac.id/index.php/mib

DOI 10.30865/mib.v5i2.2959

Res. J. Eng. Technol., vol. 4, no. 8, pp. 2276-2281, 2017, [Online]. Available: https://irjet.net/archives/V4/i8/IRJET-V4I8411.pdf.

[10] Z. Wu, W. Lin, Z. Zhang, A. Wen, and L. Lin, "An Ensemble Random Forest Algorithm for Insurance Big Data Analysis," Proc. - 2017 IEEE Int. Conf. Comput. Sci. Eng. IEEE/IFIP Int. Conf. Embed. Ubiquitous Comput. CSE EUC 2017, vol. 1, pp. 531-536, 2017, doi: 10.1109/CSE-EUC.2017.99.

[11] Y. Al Amrani, M. Lazaar, and K. E. El Kadiri, "A novel hybrid classification approach for sentiment analysis of text document," Int. J. Electr. Comput. Eng., vol. 8, no. 6, pp. 4554-4567, 2018, doi: 10.11591/ijece.v8i6.pp4554-4567.

[12] M. M and S. Mehla, "Sentiment Analysis of Movie Reviews using Machine Learning Classifiers," Int. J. Comput. Appl., vol. 182, no. 50, pp. 25-28, 2019, doi: 10.5120/ijca2019918756.

[13] S. L. Mahfiz and A. Romadhony, "Aspect-based Opinion Mining on Beauty Product Reviews," 2020 3rd Int. Semin. Res. Inf. Technol. Intell. Syst. ISRITI 2020, pp. 488-493, 2020, doi: 10.1109/ISRITI51436.2020.9315350.

[14] Y. Lin, X. Wang, and A. Zhou, "Opinion spam detection," Opin. Anal. Online Rev., no. May, pp. 79-94, 2016, doi 10.1142/9789813100459_0007.

[15] J. Li, H. Yang, and C. Zong, "Document-level Multi-aspect Sentiment Classification by Jointly Modeling Users, Aspects, and Overal Ratings," Proc. 27th Int. Conf. Comput. Linguist., pp. 925-936, 2018, [Online]. Available: https://www.tripadvisor.com/.

[16] F. F. Rahmawati and Y. Sibaroni, "Multi-Aspect Sentiment Analysis pada Destinasi Pariwisata Yogyakarta Menggunakan SVM dan Particle Swarm Optimization sebagai Seleksi Fitur," 2019. 